\title{
Stylistic Preference of Scientifically Gifted Students
}

\author{
Ki-Soon Han \\ Incheon National University, Incheon, Korea \\ Email: han@inu.ac.kr
}

How to cite this paper: Han, K.-S. (2017). Stylistic Preference of Scientifically Gifted Students. Creative Education, 8, 1991-1997. https://doi.org/10.4236/ce.2017.812135

Received: January 11, 2017

Accepted: September 26, 2017

Published: September 29, 2017

Copyright $\odot 2017$ by author and Scientific Research Publishing Inc. This work is licensed under the Creative Commons Attribution International License (CC BY 4.0).

http://creativecommons.org/licenses/by/4.0/

\begin{abstract}
This study aims to show how scientifically gifted students think in terms of Thinking Style Inventory based on Sternberg's theory of mental self-government. Two hundred and fifty-six middle school students who enrolled in a gifted education program participated in this study. Results indicated that scientifically gifted students prefer legislative, liberal, judicial thinking styles, in comparison to general students, known to be related to creative and critical thinking rather than executive and conventional styles. Implications for gifted education based on the findings are discussed.
\end{abstract}

\section{Keywords}

Thinking Style, Scientifically Gifted, Preference, Gifted Education

\section{Introduction}

Many psychologists and educators have attributed students' successes and failures in academic achievement mainly to individual differences in abilities, and scholars have recently started to examine other factors that affect students' learning outcomes. One of the major interesting factors investigated is the "style" construct (Cano-Garcia \& Hughes, 2000; Sternberg, 1999; Zhang, 2001). Sternberg (1999) pointed out that one cannot fully understand intellectual abilities unless one also knows about thinking styles which are how individuals apply them in adapting to the demands of the environment. Introducing the notion of thinking styles, Sternberg expanded people's notion from "what people can do" to "what people prefer to do"-how they capitalize on the abilities they have. Sternberg and Grigorenko (1993) indicated that gifted students can be most successful if they pursue tasks that match their abilities and styles.

In the early 1990s, two theories of styles that address multiple dimensions of 
styles were proposed. One is Riding's (1991) theory of cognitive style dimension (verbal imagery and who list analytic); the other is Sternberg's theory of mental self-government (Sternberg, 1990; 1999). The present study is based on the latter theoretical foundation. The basic assumption of Sternberg's theory of mental self-government is that the way individuals use their mind is analogous to various dimensions of government in the external world. Like the political concept of government, mental self-government has five dimensions: function, form, level, scope, and leaning.

Analogous to the three branches of the U.S. government, there are three primary functions of mental self-government. The legislative function is concerned with formulating ideas and creating rules. The executive function is concerned with carrying out plans and implementing rules initiated by others. The judicial function mainly involves comparing and evaluating ideas, rules, and procedures. Although no one can be viewed as exclusively legislative, executive, or judicial, individuals tend to have distinct dominant style preferences. In contrast to the three functions, forms of mental self-government concerns various styles of goal-setting and self-management behaviors, such as prioritizing (Hierarchic), pursuing goals single-mindedly (Monarchic), having multiple goal pursuits (Oligarchic), and taking a random approach to goals and problems (Anarchic). Furthermore, levels of mental self-government distinguish between a preference for problems at a relatively high level of abstraction (Global) and a preference for problems that demand attention to details (Local). Scope of self-government refers to a preference for tasks that allow one to work alone, independent of others (internal), versus a preference for tasks that allow social interaction and collaboration (External). Finally, leaning of self-government refers to individual preferences for unfamiliar, ambiguous, new, and challenging tasks (Liberal) or preferences for tasks which require familiarity and adherence to existing rules (Conservative) (Dai \& Feldhusen, 1999).

According to Sternberg (1999), these style constructs are not typological nor dichotomous but nomothetic and continuous in nature. In other words, stylistic differences are not a matter of whether one possesses or does not possesses a specific style but a matter of the degree of that particular thinking preference. Furthermore, these styles are not completely innate but developed and socialized and reflect tasks or situational demands as well as individual dispositions (Sternberg \& Grigorenko, 1993; Dai \& Feldhusen, 1999).

Understanding individuals' thinking styles can be useful in that it helps to understand learners' diversity in class and to connect learners' characteristics and teaching approaches. Sternberg and Gregorinko (1993) suggested thinking style as an important factor to consider to understand and to facilitate giftedness. Thinking style perspective can shed light on various issues and controversies in gifted education, such as identification, programming, grouping, and evaluation. Although Sternberg and Grigorenko (1993) discussed the theoretical and practical implications of the thinking styles for general and gifted education, 
research that applies this model of thinking style to gifted students to understand characteristics or patterns of gifted students' thinking styles is very rare.

Thus it is the purpose of the present study to examine scientifically gifted students' thinking style patterns based on Sternberg's theory of mental self-government. Though Dai and Feldhusen (1999) studied thinking styles in gifted students in general, there has been no study so far to deal with scientifically gifted students in particular. Recent studies (e.g., Han, 2003; Han \& Marvin, 2002) suggested that giftedness and creativity can be better understood as domain-specific. Therefore, it would be meaningful to examine thinking styles among scientifically gifted students in specific and draw implications for them.

\section{Methods}

\subsection{Sample}

Two hundred and fifty-six middle school students who were admitted in the Incheon Science Elite Program (ISEP) at the University of Incheon participated in the present study. To be admitted at the ISEP, students had to pass through the three-step identification procedures: recommendations from the school principals and teachers; a paper-and-pencil to assess scientific knowledge and creative problem solving abilities in specific science areas; and in-depth interview. Among the 256 students, 163 (64\%) students were male and 93 (36\%) were female. The majority of the students were $8^{\text {th }}$ grades $(n=184,96 \%)$, and there were thirteen $(5 \%) 7^{\text {th }}$ grades and sixty-nine $9^{\text {th }}$ grades. To compare scientifically gifted students' thinking styles with those of normal students (non-gifted group), 173 normal students in a middle school in the area of Incheon participated. Among the 173 students, 93 were male and 80 were female. There were thirteen $7^{\text {th }}$ grade and one hundred and sixty $8^{\text {th }}$ grade students.

\subsection{Instruments}

Thinking Style Inventory (TSI)

“Thinking Style Inventory short version” (Sternberg \& Wagner, 1991; Sternberg, 1999) which includes 65 items, is arranged in 13 scales that measure 13 thinking styles. Respondents were asked how well each item describes them. The median value of the coefficient $\alpha$ to these scales is 0.77 for college students with Legislative (0.76), Executive (0.81), Judicial (0.72), Monarchic (0.42), Hierarchic (0.80), Anarchic (0.53), Oligarchic (0.81), Global (.078), Local (0.54), Internal (0.77), External (0.88), Conservative (0.77), and Progressive (0.87). Construct validity was also notable. Factor analysis of these scales demonstrated the existence of five factors, four of which were perfectly coherent with the theoretical model.

\section{Results \& Discussion}

Alpha reliability coefficients were computed for the 13 subscales for the sample. Except for the measures of Oligarchic and Anarchic styles, reliability coefficients of these subscales were reasonably high, ranging from 0.44 to 0.83 for gifted 
group (0.47 to 0.78 for normal group). Since low reliabilities of Oligarchic and Anarchic styles were apparent and problematic in previous studies (Dai \& Feldhusen, 1999; Yoon, 1999), those two measures were excluded in the following statistical analyses.

To answer the first research question, examining scientifically gifted students' thinking style patterns, gifted students' and normal students' thinking style scores on 11 subscales were compared. Gifted students scored higher than normal students overall, except the Conservative subscale. In the Conservative subscales, normal students scored higher than gifted group. T-Test was run to examine whether these mean differences between these two groups have statistical significance. There were significant statistical differences in 9 out of 11 subscales between gifted and normal students. There were no significant differences in the Global and the External subscales. The comparison between gifted and normal students suggests that gifted students may be more legislative, executive, and judicial than normal students. In the aspect of level, gifted students tended to be more local. Looking at the aspect of leaning shows that gifted students were likely to be more liberal and less conservative than normal students. In the forms of the mental self government theory, gifted students were also more monarchic and hierarchic. In addition, gifted students were more likely to be internal than normal students. Cohen's d value indicates that the largest differences between the two groups exist in judicial, legislative, local, and liberal subscales in order.

Though the results are not consistent exactly with previous one, these results are similar with Dai and Feldhusen's (1999) previous findings in that gifted students tended to show strong legislative, liberal, and judicial styles. The findings of the present study and the previous one (Dai \& Feldhusen, 1999) may suggest that scientifically gifted students in specific and gifted students in general do show and share common thinking style patterns.

To explore the internal validity of the thinking style inventory, factor analysis and Pearson correlation analysis were conducted. Since it is the purpose of the study to explore patterns of thinking styles and factor structure for scientifically gifted students, those analyses conducted for the gifted group are presented here. Confirming the previous finding that there was a substantial overlap between legislative-executive and liberal-conservative dimensions (Sternberg, 1994), legislative style was highly correlated with liberal style $(\mathrm{r}=0.68, \mathrm{p}<0.001)$, as was the correlation between executive and conservative styles $(\mathrm{r}=0.39, \mathrm{p}<0.001)$. As indicated in Sternberg's (1994) previous research, there was also significant correlation between judicial style and hierarchic style $(\mathrm{r}=0.46, \mathrm{p}<0.001)$.

Significant negative correlations were found between the subscales that contrast in their concepts. The negative correlations between conservative and liberal styles $(\mathrm{r}=-0.58, \mathrm{p}<0.001)$, internal and external styles $(\mathrm{r}=-0.44, \mathrm{p}<0.001)$, and global and local styles $(r=-0.38, p<0.001)$ suggest that these conceptually opposite stylistic dimensions may be independent of each other and mutually 
exclusive, supporting Sternberg's mental self government theory. However, the sizes of the inverse correlations in this study were much smaller than previous findings (Sternberg, 1994), implying that the opposite thinking styles are far less antithetical than the previous study has suggested. In fact, it is needed to clarify whether the opposite styles in the thinking styles inventory are rather discrete or bipolar in nature. Sternberg (1994) has suggested that these tend to be bipolar in nature, but more recent studies (e.g., Dai \& Feldhusen, 1999; Yoon, 1999) support that these are more likely to be discrete.

An explorative analysis with varimax rotation was conducted to determine the pattern of relationships of the 11 subscales and higher-order factor constructs. The underlying factor structure of the thinking style inventory in the present study suggests fewer dimensions than postulated by Sternberg's mental self-government theory. Factor analysis yielded four factors with eigenvalues greater than one, accounting for $71 \%$ of the total variance. The first factor subsumes legislative-executive styles and liberal-conservative styles. The legislative-liberal styles in factor one seem to be related to the intellectual independence and creative thinking. Since the executive-conservative styles in factor one are conceptually opposite to the legislative-liberal styles and negatively loaded, these also seem to support the gifted students' disposition for independence and creative and innovative thinking. The second factor subsumes executive, judicial, conservative, and hierarchic styles. The styles gathered in second factor apparently contradict with those in factor one. The second factor seems to be characterized by the term, such as rule, regulation, system and so on, which suggests the individual preference to follow rule and regulations and to do things systematically. But it is also noted that judicial style in factor two is associated with critical and analytical thinking, indicating gifted students' disposition for doing and working on things both systematic and analytic manner. The third factor subsumes internal-external styles, and is explained as the scopes in the mental self-government theory. Finally, fourth factor subsumes global-local styles that are levels in the mental self-government theory. Though a few styles were cross loaded, the four factors seemed relatively independent of one another. These results suggest that Sternberg's thinking style inventory can be organized into higher-order dimensions.

The factor patterns addressed in the present study were different from what Sternberg (1994) has originally suggested, but were similar to the ones in the previous research with gifted students (Dai \& Feldhusen, 1999). For a sample of 92 gifted students, Dai and Feldhusen (1999) drew three factors. They named the first factor as "intellectual independence" and the second factor as "executive-methodological functioning". As these results show, thinking styles inventory may be less discriminative of different dimensions of stylistic difference among gifted or high-ability sample. Nevertheless, as Dai and Feldhusen (1999) also indicated, the results of the study suggest that scientifically gifted students show diverse range of thinking styles despite the fact that they have a relatively 
homogeneous profile of academic and abilities and achievement.

\section{Implications}

The present study suggested that scientifically gifted students do differ in their thinking styles from the general students. In the process of identification, programming, and evaluation, the stylistic preference of gifted students can be very informative. Students function best when tasks and situations match their abilities and styles. For example, a gifted student with an executive style will enjoy being a consumer of knowledge, whereas a gifted student with a legislative style will most enjoy being a producer of knowledge. Since scientifically gifted students prefer legislative and liberal thinking styles, teaching-and-learning model that emphasizes project or problem-based learning would be more effective for them than a traditional teaching method. Although thinking styles are not good or bad in an absolute sense, they are not value-free either (Dai \& Feldhusen, 1999). Certain styles are preferred to others: the legislative, liberal, and judicial styles are preferred to the executive or conservative styles because gifted students need to develop those styles to be creative and critical thinkers. Therefore, teachers and parents must help students to learn not only how to capitalize upon preferred thinking styles and to compensate for less developed ones.

\section{Fund}

This study is supported by the Incheon National University Research fund.

\section{References}

Cano-Garcia, F., \& Hughes, E. H. (2000). Learning and Thinking Styles: An Analysis of Their Interrelationship and Influence on Academic Achievement. Educational Psychology, 20, 414-430. https://doi.org/10.1080/713663755

Dai, D. Y., \& Feldhusen, J. F. (1999). A Validation Study of the Thinking Style Inventory: Implications for Gifted Education. Roeper Review, 21, 302-307. https://doi.org/10.1080/02783199909553981

Han, K. S. (2003). Domain-Specificity of Creativity in Young Children: How Quantitative and Qualitative Data Support It. Journal of Creative Behavior, 37, 117-142.

Han, K. S., \& Marvin, C. (2002). Multiple Creativities? Investigating Domain-Specificity of Creativity in Young Children. Gifted Child Quarterly, 46, 98-109. https://doi.org/10.1177/001698620204600203

Riding, R. (1991). Cognitive Style Analysis. Birmingham, AL: Learning and Training Technology.

Sternberg, R. J. (1990). Thinking Styles: Keys to Understanding Student Performance. Phi Delta Kappan, 71, 366-371.

Sternberg, R. J. (1994). Thinking Styles: Theory and Assessment at the Interface between Intelligence and Personality. In R. J. Sternberg, \& P. Ruzgis (Eds.), Intelligence and Personality (pp. 169-187). New York: Cambridge University Press.

Sternberg, R. J. (1999). Thinking Styles. New York: Cambridge University Press.

Sternberg, R. J., \& Grigorenko, E. L. (1993). Thinking Styles and the Gifted. Roeper Re- 
view, 16, 122-130. https://doi.org/10.1080/02783199309553555

Sternberg, R. J., \& Wagner, R. K. (1991). MSG Thinking Styles Inventory Mannual. Unpublished Manuscript.

Yoon, M. S. (1999). A Validation Study of Thinking Style Inventory. The Korea Education Review, 5, 181-197.

Zhang, L. F. (2001). Do Thinking Styles Contribute to Academic Achievement beyond Self-Rated Abilities? The Journal of Psychology, 135, 621-637.

https://doi.org/10.1080/00223980109603724

Submit or recommend next manuscript to SCIRP and we will provide best service for you:

Accepting pre-submission inquiries through Email, Facebook, LinkedIn, Twitter, etc. A wide selection of journals (inclusive of 9 subjects, more than 200 journals)

Providing 24-hour high-quality service

User-friendly online submission system

Fair and swift peer-review system

Efficient typesetting and proofreading procedure

Display of the result of downloads and visits, as well as the number of cited articles Maximum dissemination of your research work

Submit your manuscript at: http://papersubmission.scirp.org/

Or contact ce@scirp.org 